\title{
The dissociation of the fluid and particle phase in the forestomach as a physiological characteristic of large grazing ruminants: an evaluation of available, comparable ruminant passage data
}

\author{
Clauss, Marcus ; Hummel, J ; Streich, W J
}

\begin{abstract}
Whether differences in digestive physiology exist between different ruminant feeding types has been an ongoing debate. In this regard, potential differences in ingesta retention have been understood to be of particular importance. We analyzed a data pool in which only mean retention time (MRT) data for the ruminoreticulum (RR) were collated that were obtained using comparable techniques with either chromium or cobalt EDTA as a fluid marker and/or with chromium-mordanted fiber of less than $2 \mathrm{~mm}$ in size as a particle marker. Data were compared using one averaged value per species. In general, the paucity of species in such a collection is striking and does not allow - in contrast to earlier statementsany final conclusions regarding the influence of body weight (BW) or feeding type on ruminant MRTs. In particular, there was no significant correlation between MRTparticlesRR or MRTfluidRR and BW, neither in the interspecific nor in the intraspecific comparisons, and no difference between the feeding types. The trend that indicates longer MRTparticlesRR in grazers is based on too few species to be conclusive. Small browsers seemed to have shorter MRTfluidRR than similar-sized grazers. In contrast, there was a trend for large grazers to have shorter MRTfluidRR than large browsers. In direct pair-wise comparisons between cattle and the browsers giraffe, moose, and okapi, the latter difference was significant. Cattle also had the highest relative RR fluid outflow rates among the species investigated. This is in accord with the observation that grazers have larger omasa, a major function of which is water-reabsorption distal to the RR. Grazers seem to have longer MRTparticlesRR per unit MRTfluidRR, and cattle are particular outliers in this respect. It is hypothesized that potentially shorter MRTfluidRR in large grazers and higher relative outflow rates are linked to a higher saliva production and a lesser viscosity of both saliva and RR fluids. A constant supply of a fluid phase of low viscosity is proposed to be the prerogative for the physical mechanisms of flotation and sedimentation that result in the stratification of RR contents and its selective particle retention typical for large grazing species.
\end{abstract}

DOI: https://doi.org/10.1007/s10344-005-0024-0

Posted at the Zurich Open Repository and Archive, University of Zurich

ZORA URL: https://doi.org/10.5167/uzh-2400

Journal Article

Published Version

Originally published at:

Clauss, Marcus; Hummel, J; Streich, W J (2006). The dissociation of the fluid and particle phase in the forestomach as a physiological characteristic of large grazing ruminants: an evaluation of available, comparable ruminant passage data. European Journal of Wildlife Research, 52(2):88-98.

DOI: https://doi.org/10.1007/s10344-005-0024-0 
Marcus Clauss · Jürgen Hummel • W. Jürgen Streich

\section{The dissociation of the fluid and particle phase in the forestomach as a physiological characteristic of large grazing ruminants: an evaluation of available, comparable ruminant passage data}

Received: 6 September 2005 / Accepted: 4 November 2005 / Published online: 6 January 2006

(C) Springer-Verlag 2006

\begin{abstract}
Whether differences in digestive physiology exist between different ruminant feeding types has been an ongoing debate. In this regard, potential differences in ingesta retention have been understood to be of particular importance. We analyzed a data pool in which only mean retention time (MRT) data for the ruminoreticulum (RR) were collated that were obtained using comparable techniques with either chromium or cobalt EDTA as a fluid marker and/or with chromium-mordanted fiber of less than $2 \mathrm{~mm}$ in size as a particle marker. Data were compared using one averaged value per species. In general, the paucity of species in such a collection is striking and does not allow-in contrast to earlier statements - any final conclusions regarding the influence of body weight (BW) or feeding type on ruminant MRTs. In particular, there was no significant correlation between $\mathrm{MRT}_{\text {particles }} \mathrm{RR}$ or $\mathrm{MRT}_{\text {fluid }} \mathrm{RR}$ and $\mathrm{BW}$, neither in the interspecific nor in the intraspecific comparison, and no difference between the feeding types. The trend that indicates longer $\mathrm{MRT}_{\text {particles }}$ $\mathrm{RR}$ in grazers is based on too few species to be conclusive.
\end{abstract}

\section{Clauss $(\bowtie)$}

Division of Zoo Animals, Exotic Pets and Wildlife,

Vetsuisse Faculty, University of Zurich,

Winterthurerstr. 260,

8057 Zurich, Switzerland

e-mail: mclauss@vetclinics.unizh.ch

Tel.: +41-44-635-8376

Fax: +41-44-635-8901

\section{J. Hummel}

Institute of Animal Science, Department of Animal Nutrition,

University of Bonn,

Endenicher Allee 15,

53115 Bonn, Germany

\section{J. Hummel}

Zoological Garden of Cologne,

Riehler Str. 173,

50735 Cologne, Germany

W. J. Streich

Institute for Zoo and Wildlife Research (IZW),

Alfred-Kowalke-Str. 17,

10315 Berlin, Germany
Small browsers seemed to have shorter $\mathrm{MRT}_{\text {fluid }} \mathrm{RR}$ than similar-sized grazers. In contrast, there was a trend for large grazers to have shorter $\mathrm{MRT}_{\text {fluid }} \mathrm{RR}$ than large browsers. In direct pair-wise comparisons between cattle and the browsers giraffe, moose, and okapi, the latter difference was significant. Cattle also had the highest relative RR fluid outflow rates among the species investigated. This is in accord with the observation that grazers have larger omasa, a major function of which is water-reabsorption distal to the RR. Grazers seem to have longer MRT particles $R R$ per unit $M_{R T} T_{\text {fluid }} R R$, and cattle are particular outliers in this respect. It is hypothesized that potentially shorter $\mathrm{MRT}_{\text {fluid }} \mathrm{RR}$ in large grazers and higher relative outflow rates are linked to a higher saliva production and a lesser viscosity of both saliva and RR fluids. A constant supply of a fluid phase of low viscosity is proposed to be the prerogative for the physical mechanisms of flotation and sedimentation that result in the stratification of RR contents and its selective particle retention typical for large grazing species.

Keywords Mean retention time - Rumen - Omasum · Saliva $\cdot$ Browser $\cdot$ Grazer $\cdot$ Viscosity

\section{Introduction}

In the debate on physiological consequences of the differentiation of ruminants into feeding types, the question whether there are differences in ingesta passage rate between the feeding types has been a major focus of attention (Hofmann 1989; Gordon and Illius 1994; Robbins et al. 1995; Clauss and Lechner-Doll 2001). Researchers supporting or contradicting potential morphophysiological differences have both emphasized that a quantitative understanding of ingesta retention mechanisms is pivotal for a comprehensive view of ruminant ecophysiology (Kay 1987a; Illius and Gordon 1992; Owen-Smith 1996; Jiang and Hudson 1996). This is due to the fact that there are probably systematic differences between grass and browse, insofar as a longer retention of grass will result in a 
significant increase in energy gain, whereas this is much less the case for browse (Demment and Van Soest 1985). To gain insight on the correlation of ingesta passage rates and body size on the one hand, and feeding types on the other hand, different data collections were compiled. Gordon and Illius (1994) collated data on particle mean retention time (MRT) in the whole gastrointestinal tract (GIT) of ruminants and concluded that there was a strong correlation to body weight (BW), but no difference between the feeding types for this parameter. In a similar way, Robbins et al. (1995) collated data on liquid outflow from the ruminoreticulum (RR) and RR fluid passage rates; they did not find any difference between the feeding types and liquid RR outflow was highly correlated to BW. In contrast, RR fluid passage rates did not correlate to BW, but neither these nor other authors commented further on this finding. Clauss and Lechner-Doll (2001) criticized the methods of data compilation in these studies. They collated literature evidence on physiological measurements that indicate a faster particle passage in browsers and proposed the use of the "selectivity factor," originally defined as the ratio of $\mathrm{MRT}_{\text {particles }} \mathrm{RR} / \mathrm{MRT}_{\text {fluid }} \mathrm{RR}$ by Lechner-Doll et al. (1990), and thereby demonstrated potential differences between the feeding types with grazers displaying high and browsers low values for this quotient. However, these authors did not investigate whether this effect was due to longer $\mathrm{MRT}_{\text {particles }} \mathrm{RR}$ or shorter $\mathrm{MRT}_{\text {fluid }} \mathrm{RR}$ in grazers, or a combination of both.

To differentiate between different classes of forestomach physiology when comparing passage rates in ruminants, it is important to only use data for the MRT in the RR, not in the total GIT. Total GIT MRT may differ significantly with respect to a species' adaptation to water conservation in the distal colon. This was exemplified, for instance, by Behrend et al. (2004), comparing values for mouflon from a temperate and sheep from an arid environment. Fecal dry matter concentrations can vary drastically between ruminant species (Clauss et al. 2004), and Woodall and Skinner (1993) showed that this correlates to the length of the distal colon where water reabsorption occurs. Thus, e.g., desert species would be expected to have longer total tract MRTs compared to species of similar RR physiology from temperate environments.

An important aspect of comparing MRT data is the method by which it was derived. Different marker systems can yield different estimates. Particle size is an important determinant of $\mathrm{MRT}_{\text {particles }} \mathrm{RR}$ in ruminants (Lechner-Doll et al. 1991), and therefore, only data referring to a (standardized) similar particle size should be compared. Particles for the measurement of ingesta retention can be labeled by different substances, which differ in their binding characteristics and hence in the results they yield. These differences were discussed in detail by Warner (1981). For ruminants, Poncet and Al Abd (1984) showed that the two most common marker systems for particles, chromium $(\mathrm{Cr})$ mordants, and ytterbium-labeled particles yield results that are not comparable. The same authors showed that results for the two most common liquid markers - polyethylene glycol and a combination of EDTA and a metal (Cr- or Co-EDTA) are not comparable. The sampling regime can also influence the results: If feces are collected as often as possible, mostly shorter MRTs will be calculated compared to studies where only one or two pooled fecal sample per day are analyzed (as in Foose 1982). Finally, a variety of mathematical models for the calculation of MRT exists (e.g., Amici et al. 1997).

Another important aspect in comparing MRT data is the effect of the feeding level and food characteristics on the measured results. For example, animals of different digestive tract systems all had faster total tract passage rates on alfalfa as opposed to grass hay (Foose 1982); however, in that study, intake was also invariably higher on the alfalfa hay diet. If interspecific comparisons are attempted, the paucity of existing data leads to the inclusion of measurements made on very variable diets.

In this collation of comparable data we intended to test whether the available data allowed any conclusions with regard to quantitative differences in retention mechanisms between grazing and browsing ruminant species. In particular, we intended to elucidate whether the high ratios of particle to fluid retention observed in grazers are the result of longer particle or shorter fluid retention times, or both. Finally, we propose a hypothetical explanation of our findings that emphasizes a parameter that has received little attention in the comparative literature so far: the viscosity of ruminant saliva and rumen fluid.

\section{Materials and methods}

Data were collected only from studies that gave at least average values or ranges for the BWs of the animals used, that measured retention times in the RR, that used Cr- or Co-EDTA as fluid marker, and/or that used $\mathrm{Cr}$-mordanted fiber of a particle size $<2 \mathrm{~mm}$, prepared according to Udén et al. (1980), as a particle marker. These choices automatically excluded the one major comparative study on wild herbivores in which MRT data for the whole GIT was generated by analyzing one or two pooled fecal samples per day (Foose 1982).

In publications in which no direct values for retention time and outflow rate were given, fluid MRT in the RR was calculated as the reciprocal of the fractional outflow rate $(k)$, and rumen outflow rate was calculated by multiplying RR fluid volume with $k$. In publications in which the total tract MRT for fluids and particles was given, $M_{R} T_{\text {fluid }} R R$ and $\mathrm{MRT}_{\text {particles }} \mathrm{RR}$ were calculated according to LechnerDoll et al. (1990) by first calculating the fluid MRT for the tract distal to the RR by the subtraction of $\mathrm{MRT}_{\text {fluid }} \mathrm{RR}$ from $\mathrm{MRT}_{\text {fluid }} \mathrm{GIT}$, and then by subtracting the resulting value from $\mathrm{MRT}_{\text {particles }}$ GIT. This procedure assumes that no significant difference in distal tract MRT exists between particles and fluids, an assumption that was principally confirmed by Grovum and Williams (1973), Kaske and Groth (1997), Mambrini and Peyraud (1997).

Data were available for domestic cattle (Bos taurus), water buffalo (Bubalus bubalus), domestic sheep (Ovis ammon aries), mouflon (Ovis ammon musimon), wapiti 
Fig. 1 Correlation between BW and $\mathrm{MRT}_{\text {particles }} \mathrm{RR}$ in different ruminant feeding types - one average value per species. Regression lines: dotted, grazer and solid, browser. There is no significant correlation with BW within any feeding type or for the whole data set; the number of species is too low to allow a reasonable comparison between the feeding types

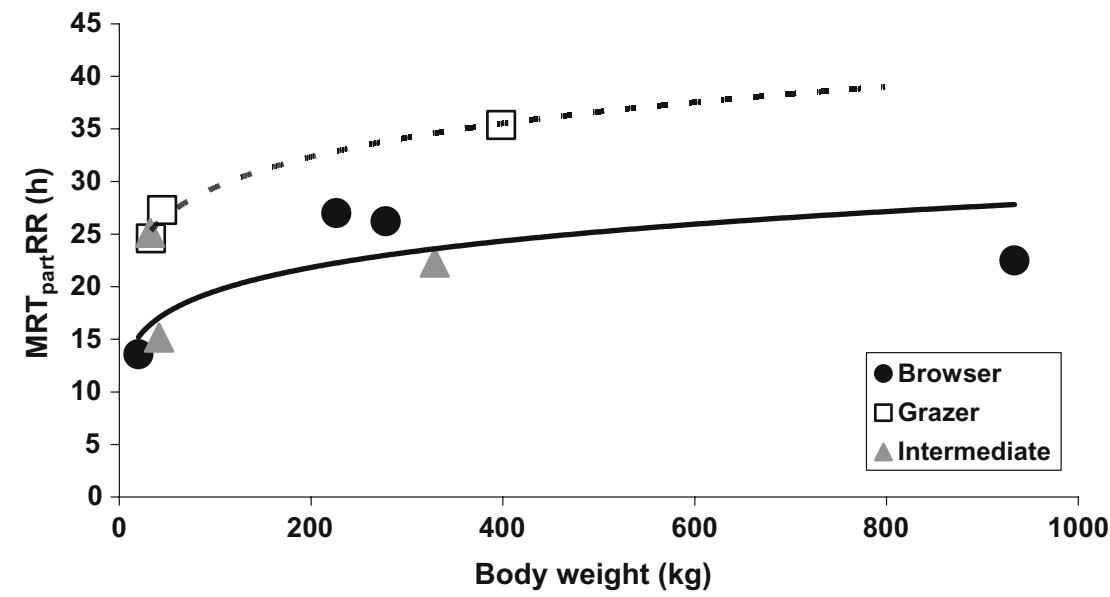

(Cervus elaphus wapiti), red deer (Cervus elaphus elaphus), domestic goat (Capra hircus), giraffe (Giraffa camelopardalis), moose (Alces alces), okapi (Okapia johnstoni), mule deer (Odocoileus hemionus), white-tailed deer (Odocoileus virginianus), and roe deer (Capreolus capreolus) and was collated from the following sources:

1. $\mathrm{MRT}_{\text {particles }} \mathrm{RR}$

We used data from Udén et al. ( 1982), Van Bruchem et al. (1984, read from graph), Kennedy (1985), Lindberg (1985, read from the graph), Okine et al. (1989), Renecker and Hudson (1990), Burns et al. (1997), Clauss et al. (1998), Behrend (2000), Hummel (2003), and the original datasets from Lechner-Doll et al. (1990) and Gross et al. (1996).

2. $\mathrm{MRT}_{\text {fluid }} \mathrm{RR}$

We used data from Faichney and Griffiths (1978), Faichney (1980), Hendricksen et al. (1981), Poppi et al. (1981a,b), Goetsch and Galyean (1982), Hjeljord et al. (1982), Udén et al. (1982), Varga and Prigge (1982), Colucci et al. (1984), Poncet and Al Abd (1984), Prigge et al. (1984), Van Bruchem et al. (1984, read from graph), Kennedy (1985), Ledoux et al. (1985), Lindberg (1985, read from the graph), McCollum and Galyean (1985), Majak et al. (1986), Merchen et al. (1986), Funk et al. (1987), Krysl et al. (1987), Shaver et al. (1988), Jacques et al. (1989), Okine et al. (1989), Branine and Galyean (1990), Renecker and Hudson (1990), Moore et al. (1990), Tatman et al. (1991),
Arthun et al. (1992), Kattnig et al. (1992), Kennedy et al. (1992), Spalinger et al. (1993), Freudenberger et al. (1994), Holand (1994), Robbins et al. (1995, citing Spalinger and Murden, unpublished article, read from graph), Hatt et al. (1998, individual data from Hatt 1996), Bartocci et al. (1997), De Vaga and Poppiof (1997), Burns et al. (1997), Kaske and Groth (1997), Clauss et al. (1998), Behrend (2000), Tafaj et al. (2001, 2002), Hummel (2003), and the original datasets from Lechner-Doll et al. (1990) and Gross et al. (1996).

3. RR fluid outflow rates

We used data from Poppi et al. (1980a,b), Goetsch and Galyean (1982), Varga and Prigge (1982), Colucci et al. (1984), Prigge et al. (1984), Dixon and Milligan (1985), McCollum and Galyean (1985), Merchen et al. (1986), Funk et al. (1987), Krysl et al. (1987), Jacques et al. (1989), Renecker and Hudson (1990), Tatman et al. (1991), Arthun et al. (1992), Spalinger et al. (1993), Robbins et al. (1995, citing Spalinger and Murden, unpublished article, read from graph), Kaske and Groth (1997), Behrend (2000), and the original dataset from Lechner-Doll et al. (1990).

According to Illius and Gordon (1992) and McNab (2002), MRTs were assumed to correlate allometrically to BW. As an allometric analysis of the correlation between RR outflow and BW tended to yield an exponent equal to 1 , a linear correlation between these two parameters was assumed.
Table 1 Correlation analysis (Pearson's correlation coefficient, PCC) for $\mathrm{MRT}_{\text {particles }} \mathrm{RR}$ and $\mathrm{BW}$ for the available literature data of different ruminant species and feeding types

$n_{\mathrm{g}}$ is the number of groups included (see Materials and methods), e.g., $n=13$ and $n_{\mathrm{g}}=2$ means: this correlation is based on 11 measurement pairs of single animals and 2 group mean pairs

\begin{tabular}{lcccc}
\hline Feeding type/species & $\mathrm{n}$ & $n_{\mathrm{g}}$ & PCC & $p$ \\
\hline One average value per species & & & & \\
Grazer & 3 & - & 0.977 & 0.137 \\
Browser & 4 & - & 0.292 & 0.708 \\
(Groups of) individuals within a species & & & \\
Cattle & 13 & 2 & -0.140 & 0.647 \\
Sheep & 16 & 3 & -0.377 & 0.150 \\
Ibex & 8 & 0 & 0.595 & 0.120 \\
Goat & 11 & 0 & -0.446 & 0.170 \\
Giraffe & 3 & 0 & 0.994 & 0.070 \\
Okapi & 8 & 0 & -0.603 & 0.397 \\
\hline
\end{tabular}


Fig. 2 Correlation between BW and $\mathrm{MRT}_{\text {fluid }} \mathrm{RR}$ in different ruminant feeding types - one average value per species. Regression lines: dotted, grazer and solid, browser. There is no significant correlation with BW within any feeding type or for the whole data set; the number of species is too low to allow a reasonable comparison between the feeding types

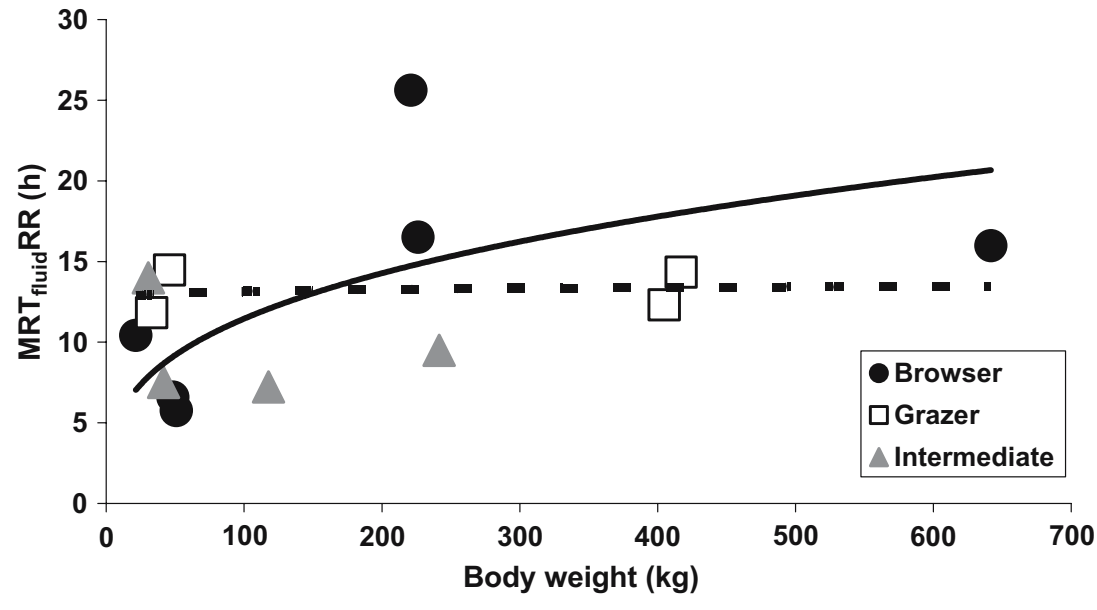

Data were compiled for individual animals whenever possible and only one average value per individual was used for the further calculation of a species average. If data were available for a group of animals only, its average was used for the calculation of the species average after multiplication with its number of individuals in that respective animal group. Such groups were also included in the calculation of Pearson's correlation coefficient (PCC) between retention time and $\mathrm{BW}$ or $\mathrm{MRT}_{\text {fluid }} \mathrm{RR}$ and $\mathrm{MRT}_{\text {particles }} \mathrm{RR}$ in the intraspecific comparisons. In the latter calculations, however, each group contributed just a single data pair (like a single animal), because considering the group's multiplicity would potentially distort the respective $p$ value. The $t$ test was used to compare animals of different species concerning their retention time. In case of multiple tests, the significance was evaluated according to the Dunn/Sidak method (Sokal and Rohlf 1997). ANOVA or analysis of covariance served to compare groups of species assigned to different feeding types. The significance level was always set to $5 \%$. All calculations were performed using the Statistical Package for the Social Sciences 9.0 (SPSS Inc., Chicago, IL, USA) statistical software package.

\section{Results}

$\mathrm{MRT}_{\text {particles }} \mathrm{RR}$

Data on $\mathrm{MRT}_{\text {particles }} \mathrm{RR}$ were available for the following species:

\begin{tabular}{lll}
\hline Species & Animal & $\begin{array}{l}\text { Number of publications from which } \\
\text { the data were derived from }\end{array}$ \\
Browsers & Roe deer & 1 \\
& Okapi & 1 \\
& Moose & 1 \\
& (one animal & \\
& only) & \\
Giraffe & 1 \\
Intermediate & Goats & 2 \\
feeders & Ibex & 1 \\
Grazers & Wapiti & 1 \\
& Mouflon & 1 \\
& Sheep & 5 \\
& Cattle & 5
\end{tabular}

The data are visualized in Fig. 1. They are not numerically sufficient to statistically evaluate differences between the feeding types. The tendency of grazing ruminants to have longer $\mathrm{MRT}_{\text {particles }} \mathrm{RR}$ than browsing species cannot be
Table 2 Correlation analysis (Pearson's correlation coefficient, PCC) for $\mathrm{MRT}_{\text {fluid }} \mathrm{RR}$ and $\mathrm{BW}$ for the available literature data of different ruminant species and feeding types $n_{\mathrm{g}}$ is the number of groups included (see legend of Table 1) ${ }^{*} \mathrm{p}<0.05$

\begin{tabular}{lcccl}
\hline Feeding type/species & $\mathrm{n}$ & $n_{\mathrm{g}}$ & PCC & $p$ \\
\hline One average value per species & & & & \\
Grazer & 4 & - & 0.108 & 0.892 \\
Browser & 6 & - & 0.479 & 0.337 \\
(Groups of) individuals within a species & & & \\
Cattle & 33 & 22 & -0.113 & 0.532 \\
Sheep & 33 & 22 & -0.042 & 0.816 \\
Ibex & 8 & 0 & 0.771 & $0.025^{*}$ \\
Goat & 12 & 1 & -0.243 & 0.447 \\
Wapiti & 3 & 1 & 0.950 & 0.203 \\
Giraffe & 6 & 0 & 0.461 & 0.357 \\
Okapi & 4 & 0 & -0.881 & 0.119 \\
Moose & 5 & 4 & -0.365 & 0.546 \\
White-tailed deer & 3 & 0 & -0.699 & 0.507 \\
Roe deer & 5 & 1 & 0.871 & 0.055 \\
\hline
\end{tabular}


Table 3 Correlation analysis (Pearson's correlation coefficient, PCC) for $\mathrm{MRT}_{\text {fluid }} \mathrm{RR}$ and $\mathrm{MRT}_{\text {particles }} \mathrm{RR}$ for the available literature data of different ruminant species and feeding types

$n_{\mathrm{g}}$ is the number of groups included (see legend of Table 1) $* \mathrm{p}<0.05$

\begin{tabular}{lrrcc}
\hline Feeding type/species & $\mathrm{n}$ & $n_{\mathrm{g}}$ & PCC & $p$ \\
\hline One average value per species & & & & \\
Grazer & 3 & - & -0.106 & 0.933 \\
Intermediate & 3 & - & 0.894 & 0.296 \\
Intermediate + grazer (without cattle) & 5 & - & 0.926 & $0.026^{*}$ \\
Browser & 4 & - & 0.763 & 0.237 \\
(Groups of) individuals within a species & & & & \\
Cattle & 13 & 2 & 0.841 & $<0.001^{*}$ \\
Sheep & 16 & 3 & 0.711 & $0.002^{*}$ \\
Mouflon & 5 & 0 & 0.909 & $0.032^{*}$ \\
Ibex & 8 & 0 & 0.914 & $0.001^{*}$ \\
Goat & 11 & 0 & 0.374 & 0.257 \\
Giraffe & 3 & 0 & 1.000 & $0.020^{*}$ \\
Okapi & 4 & 0 & 0.847 & 0.123 \\
Roe deer & 4 & 0 & 0.994 & $0.006^{*}$ \\
\hline
\end{tabular}

regarded as evidence. The allometric equation derived from these data,

$\operatorname{MRT}_{\text {particles }} \mathrm{RR}(\mathrm{h})=\mathrm{aBW}$,

was neither significant for any feeding type (grazer: $p=0.109$, intermediate feeder: $p=0.876$, browser: $p=0.205$ ) nor for all ruminant species combined $(p=0.156)$. In species in which several animals with given BWs were measured, there was no significant correlation between $\mathrm{BW}$ and $\mathrm{MRT}_{\text {particles }} \mathrm{RR}$; the calculated correlation coefficients were not even consistently positive (Table 1). Even if feeding types generally could not be compared because of the data situation, it was possible to compare individual species against each other by the use of $t$ tests. When comparing representatives of browsers and grazers, there was only the tendency for a difference in $\mathrm{MRT}_{\text {particles }} \mathrm{RR}$ between giraffe $(22.5 \pm 7.0 \mathrm{~h})$ and cattle $(35.4 \pm 10.4 \mathrm{~h}$, $p=0.055)$, no difference between giraffe and sheep $(27.3 \pm$ $8.8 \mathrm{~h}, p=0.372)$ or giraffe and mouflon $(24.6 \pm 2.6 \mathrm{~h}$, $p=0.552$ ), and no significant difference between okapi $(27.0 \pm 3.0 \mathrm{~h})$ and cattle $(p=0.132)$, sheep $(p=0.949)$, or mouflon $(p=0.230)$, respectively. In contrast, roe deer
$(13.6 \pm 2.0 \mathrm{~h})$ showed significantly shorter values than cattle $(p=0.001)$, sheep $(p=0.005)$, or mouflon $(p<0.001)$.

$\mathrm{MRT}_{\text {fluid }} \mathrm{RR}$

Data on $\mathrm{MRT}_{\text {fluid }} \mathrm{RR}$ were available for the following species:

\begin{tabular}{lll}
\hline Species & Animals & \multicolumn{2}{c}{$\begin{array}{c}\text { Number of publications from which } \\
\text { the data were derived from }\end{array}$} \\
Browsers & Roe deer & 2 \\
& White- & 1 \\
& tailed deer \\
& Mule deer & 1 \\
& Okapi & 1 \\
& Moose & 2 \\
& Giraffe & 2 \\
Intermediate & Goats & 3 \\
feeders & Ibex & 1 \\
& Wapiti & 2 \\
& Red deer & 1 \\
Grazers & Mouflon & 1 \\
& Sheep & 19 \\
& Cattle & 25 \\
& Water & 1 \\
& buffalo & \\
\hline
\end{tabular}

Fig. 3 Correlation between $\mathrm{MRT}_{\text {fluid }} \mathrm{RR}$ and $\mathrm{MRT}_{\text {particles }} \mathrm{RR}$ in different ruminant feeding types; the only data used were those where both values were determined simultaneously in individual animals, and one value per species was calculated. Regression lines: dotted, intermediate feeders and grazer (without cattle), and solid, browser. The outlying value of grazers is domestic cattle

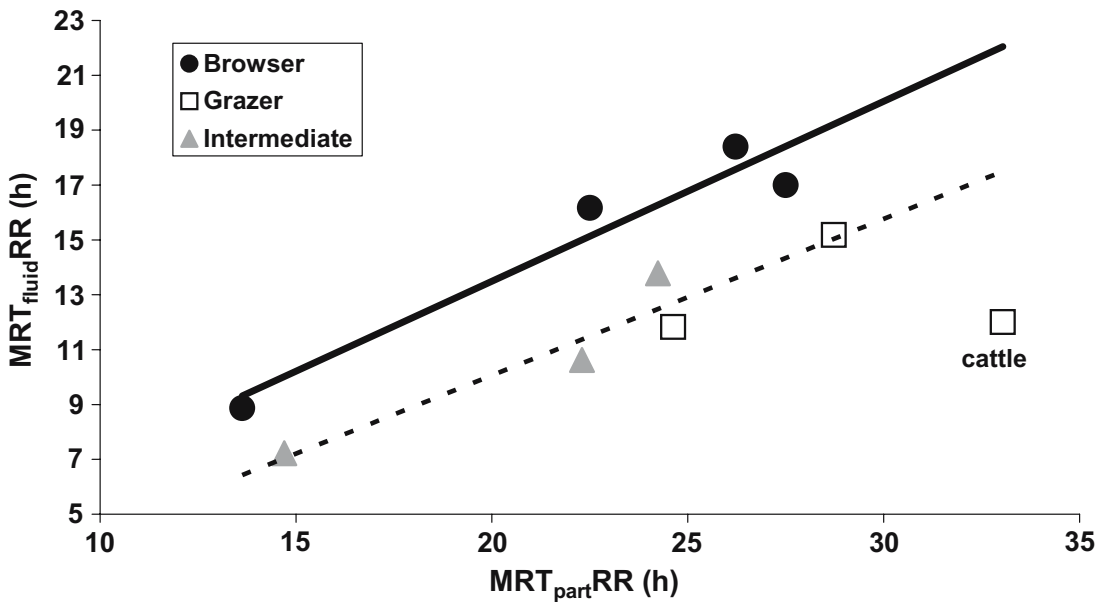


The data are visualized in Fig. 2. The allometric equations derived from these data were neither significant for any feeding type (grazer: $p=0.830$, intermediate feeder: $p=0.621$, browser: $p=0.125$ ) nor for all ruminant species combined $(p=0.122)$. In only one of the 11 species in which several individuals with given BWs were measured was there a significant correlation between BW and $\mathrm{MRT}_{\text {fluid }} \mathrm{RR}$; the calculated correlation coefficients were not even consistently positive (Table 2 ). The uncertainty concerning the correlation between $\mathrm{MRT}_{\text {fluid }} \mathrm{RR}$ and the BW and the BW gaps in the set of available species do not allow a valid comparison between the feeding types.
Without inclusion of BW (i.e., presuming no correlation), the comparison of feeding types yielded no significant difference between them (ANOVA, $p=0.501$ ). The tendency of large grazing ruminants to have shorter $\mathrm{MRT}_{\text {fluid }} \mathrm{RR}$ than browsing species cannot be regarded as evidence. Given the situation, it was, however, possible to compare individual species against each other by the use of $t$ tests. Cattle $(12.3 \pm 3.0 \mathrm{~h})$ had significantly shorter $\mathrm{MRT}_{\text {fluid }}$ RR than the large browsers giraffe $(16.0 \pm 3.1 \mathrm{~h}, p=$ $0.004)$, moose $(25.6 \pm 3.2 \mathrm{~h}, p<0.001)$, and okapi (16.5 $3.2 \mathrm{~h}, p=0.006$ ), and significantly longer $\mathrm{MRT}_{\text {fluid }} \mathrm{RR}$ than white-tailed deer $(6.6 \pm 1.2 \mathrm{~h}, p=0.0001)$; there was no
Fig. 4 Correlation between $\mathrm{MRT}_{\text {fluid }} \mathrm{RR}$ and $\mathrm{MRT}_{\text {particles }} \mathrm{RR}$ in different ruminant species of a browsers, $\mathbf{b}$ intermediate feeders, and $\mathbf{c}$ grazers; the only data used were those where both values were determined simultaneously in individual animals
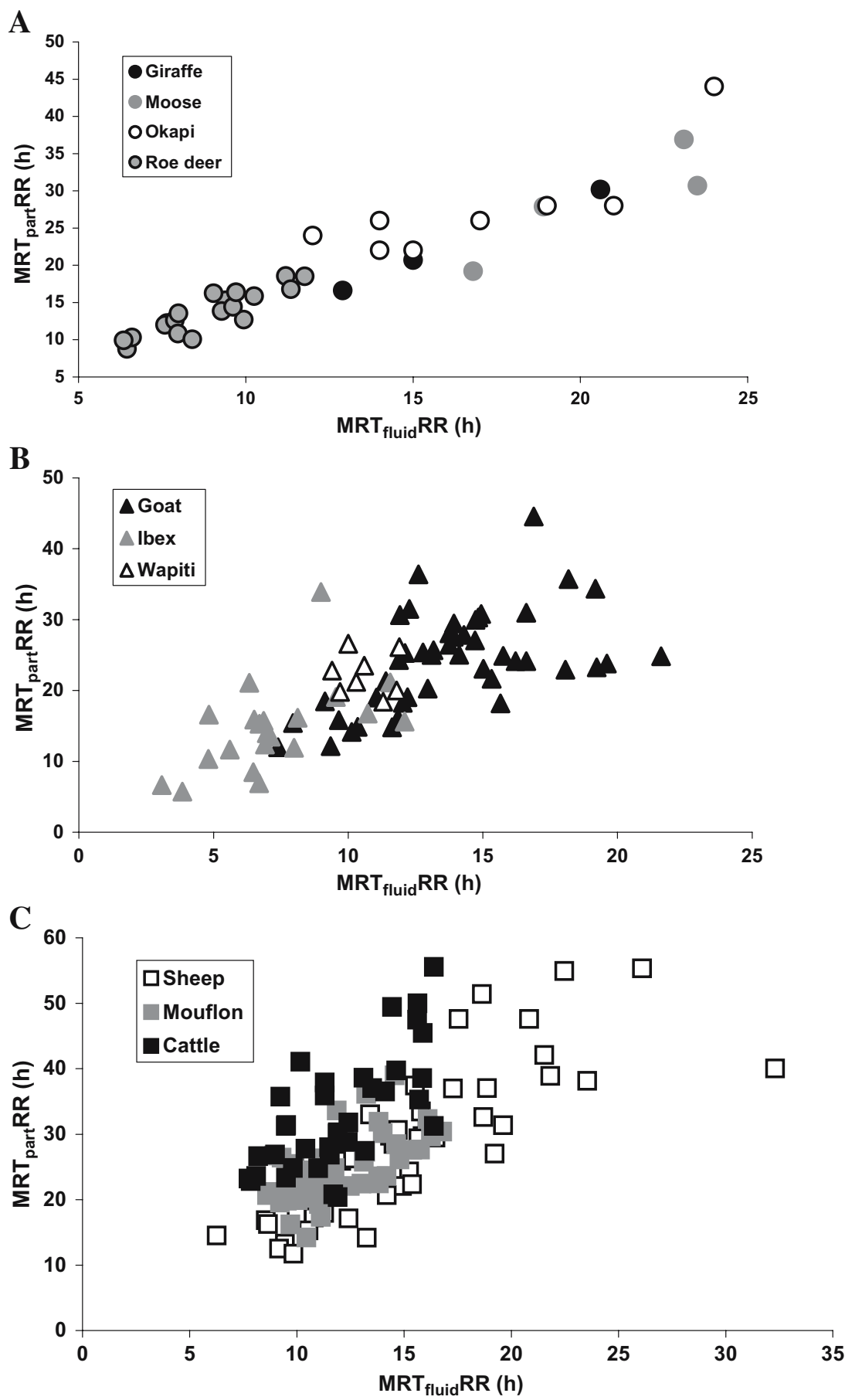
Fig. 5 Correlation of RR outflow and BW in ruminant species of different feeding type, using one value per species. Regression lines: dotted, grazer and solid, browser

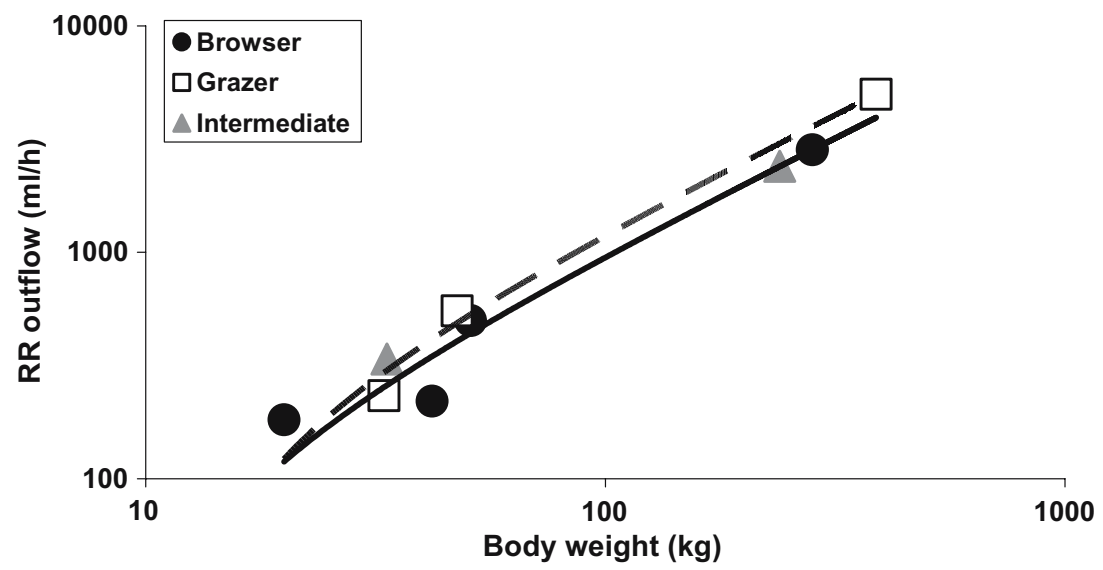

difference between cattle and roe deer $(10.4 \pm 2.5 \mathrm{~h}, p=$ $0.125)$. Moose had significantly longer $M_{R T} T_{\text {fluid }} R R$ than sheep $(14.5 \pm 4.1 \mathrm{~h}, p<0.0001)$ or mouflon $(11.8 \pm 1.1 \mathrm{~h}$, $p<0.001)$ and white-tailed deer had significantly shorter $\mathrm{MRT}_{\text {fluid }} \mathrm{RR}$ than sheep $(p=0.001)$ or mouflon $(p=0.001)$. There were no differences between giraffe, okapi or roe deer on the one hand, and sheep or mouflon on the other hand.

For all measurements in which $\mathrm{MRT}_{\text {fluid }} \mathrm{RR}$ and $\mathrm{MRT}_{\text {particles }} \mathrm{RR}$ were simultaneously measured in the same individual (or group of individuals), there were strong correlations between $\mathrm{MRT}_{\text {fluid }} \mathrm{RR}$ and $\mathrm{MRT}_{\text {particles }} \mathrm{RR}$ within species, with the exception of goat and okapi (Table 3). The correlation was stringent in browsers and intermediate feeders, but for the three grazing species available in this study combined, there was no such correlation due to the outlying value for cattle (Fig. 3). When the data for sheep and mouflon were added to that of the intermediate feeders, a stringent correlation resulted again (Table 3). In general, measurements in browsing species tended to be more uniformed (less scattered) across species than measurements in both intermediate feeders and grazers (Fig. 4). When cattle were excluded, the intercepts of the regression lines of $M_{R} T_{\text {fluid }} R R$ on $M_{R T} T_{\text {particles }} R R$ differed significantly between browsers and grazers +intermediate feeders ( $p=0.026$, see also Fig. 3 ). This means that $\mathrm{MRT}_{\text {fluid }} \mathrm{RR}$ was significantly lower for grazers or intermediate feeders than for browsers if species with similar $\mathrm{MRT}_{\text {particles }} \mathrm{RR}$ are compared. This was all the more true in comparison to cattle, which were excluded from this analysis for formal reasons (parallelity of slopes).

\section{RR fluid outflow}

Data on fluid outflow from the RR were available for the following species:

\begin{tabular}{lll}
\hline Species & Animal & \multicolumn{2}{c}{$\begin{array}{c}\text { Number of publications from which the } \\
\text { data were derived from }\end{array}$} \\
Browsers & Roe deer & 1 \\
& White- & 1 \\
& tailed deer \\
& Mule & 1 \\
& Moose & 1 \\
\hline
\end{tabular}

\begin{tabular}{cll}
\hline Intermediate & Goat & 1 \\
feeders & Wapiti & 2 \\
Grazers & Mouflon & 1 \\
& Sheep & 9 \\
& Cattle & 12 \\
\hline
\end{tabular}

The data are visualized in Fig. 5. They are not numerically sufficient to statistically evaluate differences between the feeding types. In both browsers and grazers, BW was highly correlated with RR fluid outflow (browsers: $\mathrm{PCC}=0.998, p=0.002$; grazers: $\mathrm{PCC}=0.999, \quad p=0.015$ ). An interesting tendency was that the regression lines of browsers and grazers without cattle did not differ significantly in their slope $(p=0.392)$; if, however, cattle were included in the grazers, the difference in slope became significant $(p=0.018)$. This could indicate a disproportionately high rumen fluid outflow in cattle. Expressed on a per BW basis, cattle had the highest average relative $\mathrm{RR}$ fluid outflow rate $\left(12.7 \pm 2.4 \mathrm{ml} \mathrm{h}^{-1}\right.$ $\mathrm{kg}^{-1}$ SD) when compared to sheep $\left(11.6 \pm 3.8 \mathrm{ml} \mathrm{h}^{-1} \mathrm{~kg}^{-1}\right)$, goats $\left(10.4 \pm 1.7 \mathrm{ml} \mathrm{h}^{-1} \mathrm{~kg}_{1}^{-1}\right)$, wapiti $\left(10.3 \pm 1.0 \mathrm{ml} \mathrm{h}^{-1} \mathrm{~kg}^{-1}\right)$, moose $\left(10.0 \mathrm{ml} \mathrm{h}^{-1} \mathrm{~kg}^{-1}\right.$, SD not available), mule deer $\left(9.8 \mathrm{ml} \mathrm{h}^{-1} \mathrm{~kg}^{-1}\right)$, roe deer $\left(9.1 \pm 0.2 \mathrm{ml} \mathrm{h}^{-1} \mathrm{~kg}^{-1}\right)$, mouflon $\left(7.1 \pm 0.4 \mathrm{ml} \mathrm{h}^{-1} \mathrm{~kg}^{-1}\right)$, or white-tailed deer $\left(5.2 \mathrm{ml} \mathrm{h}^{-1} \mathrm{~kg}^{-1}\right)$.

\section{Discussion}

Any discussion of results on passage characteristics between species that does not address the issue of potential differences in rations fed and food intake levels will automatically lack explanatory power. However, given the fact that earlier publications on the influence of BW or feeding type on passage characteristics did not address this question either (Illius and Gordon 1992; Gordon and Illius 1994; Robbins et al. 1995), we feel it is justifiable to assess what conclusions can be drawn from a data collection on retention times, which were at least controlled for the consistency of experimental setups used. Undoubtedly, any conclusion would have to be corroborated by more controlled studies that account for differences of both diet ingested and level of intake.

The most striking feature of the data sets compiled in this investigation is the paucity of data on both the species and 
the individual level. Many measurements available on the few browsing species were from one publication only, using only very few individuals. However, what is even more striking is the complete absence of measurements on medium-sized and large wild grazer species. In this respect, effects of domestication on the conclusions derived from such data sets cannot be ruled out, and any conclusion regarding the digestive physiology of large grazers that is based on data from cattle only must be regarded with caution. The paucity of comparable data rules out earlier claims (Gordon and Illius 1994; Robbins et al. 1995) that differences between the feeding types do not exist. They may very well exist, but we cannot test on them yet. As it is, the prediction that browsers have faster RR particle passage rates than grazers (Hofmann 1989) remains effectively untested to date (cf. Ditchkoff 2000).

An equally common claim, namely that particle retention time is a function of BW in ruminants (Illius and Gordon 1992; Gordon and Illius 1994), cannot be confirmed for the $\mathrm{RR}$ on the basis of comparable data, either. From the data compiled here, it cannot be decided whether $\mathrm{MRT}_{\text {particle }} \mathrm{RR}$ or $\mathrm{MRT}_{\text {fluid }} \mathrm{RR}$ are a function of BW or not. The lack of significance could indicate both a lack of data from more species, or the absence of such a correlation. While the general correlation between $\mathrm{BW}$ and $\mathrm{MRT}_{\text {particles }} \mathrm{RR}$ could not be confirmed on an interspecies level, presumably because of a lack of data, such a correlation could not be demonstrated either if individual data within a species are analyzed. In some cases this might be due to low sample size and a narrow BW range. However, such a correlation could also not be detected for species for which a larger number of measurements for a broader range of body sizes were available.

A surprising finding of this study is that large browsers seem to have longer fluid retention times in the RR than the representative of the large grazers - cattle. This is also reflected in higher relative RR outflow rates in cattle than in moose. Up to now, whenever differences in passage rates between the feeding types have been postulated, particles and fluids have been assumed to differ in the same way between grazers and browsers (Kay 1987a; Hofmann 1989). Shorter $M_{R T} T_{\text {fluid }} R R$ in large grazers as compared to large browsers and its higher relative RR outflow rates would be in accord with the observation of Hofmann $(1973,1989)$ that grazers have generally larger omasa than browsers of comparable size. A major function of the omasum is the reabsorption of water from the ingesta (Hauffe and von Engelhardt 1975; Edrise and Smith 1979). If it is assumed that relative RR outflow of fluids is higher in grazers than in browsers, a larger omasum in the former with a larger absorptive surface would make sense.

The fact that $\mathrm{MRT}_{\text {fluid }} \mathrm{RR}$ does not correlate with BW was already demonstrated by Robbins et al. (1995); in the data generated by Udén et al. (1982), $\mathrm{MRT}_{\text {fluid }} \mathrm{RR}$ in cattle was even shorter than in sheep and goats on a similar diet, and Colucci et al. (1984) noted that "the rate of passage of Co-EDTA was faster in cows than in sheep for all diets at both levels of intake." These observations already hint at a particular position of cattle among ruminant species. It is evident that $\mathrm{MRT}_{\text {fluid }} \mathrm{RR}$ does not follow a strict allometric pattern to BW over the body size range of ruminants.

Thus, no concluding statement on differences in passage rates between similar-sized grazers and browsers can be made, and only new hypotheses can be put forward. The data compiled in this study indicate that grazers and intermediate feeders retain particles longer in their RR per unit fluid retention time than browsers, and that cattle are particularly exceptional in this respect with very long particle retention times per unit fluid retention - or with very short fluid retention times per unit particle retention (Fig. 3). The similar value for $\mathrm{MRT}_{\text {fluid }} \mathrm{RR}$ in cattle and water buffalo (Fig. 2) suggests that in this respect, cattle are representative for other large members of the Bovinae. The observation of this dissociation of the fluid and the particle phase leads to the questions: (1) By what mechanism it is caused and (2) What are the potential consequences.

The stratification of rumen contents, i.e., the dissociation of fluids and particles, is a major prerogative for the selective retention of particles in the ruminant forestomach (Lechner-Doll et al. 1991). Differences in forage morphology were used to explain potential differences in the stratification behavior of RR ingesta between browsers and grazers (Clauss et al. 2003). However, considering the data measured by Renecker and Hudson (1990) in cattle and moose on a variety of diets, the dissociation of fluid and particle phase in cattle compared to moose seems to be unaffected by diet composition. Therefore, an intrinsic "animal factor" that determines the stratification behavior of the ingesta in the RR could be suspected to operate as well. In tradition, postulated differences in the size of intraruminal apertures were regarded as such a factor (Kay 1987a; Hofmann 1989), although the physical efficacy of such differences was not explained. A factor with more explanatory power could be the consistency of the RR fluid: For a stratification to occur, the RR fluid needs to be of a low viscosity that allows particles to move in the liquid phase - either float or sink; the lower the viscosity of the fluid, the easier movement of the particles therein. A low viscosity of RR fluid in grazing ruminants would explain why fluid MRT is more detached from particle MRT in these animals. In contrast, a higher viscosity of RR fluid in browsers could be a reason why fluid MRT is more closely associated to particle MRT in this feeding type (Table 3, Fig. 4) and why a stratification of RR contents is less prominent (Hofmann 1973; Clauss et al. 2001). A low RR fluid viscosity in grazers will explain why fermentation gases can gather easily in the dorsal rumen where their concentrated presence (and the corresponding absence of volatile fatty acids) leads to a reduction in papillation and the typical unpapillated dorsal rumen wall (Hofmann 1973). In contrast, a high RR fluid viscosity in browsers would prevent any gathering of fermentation gases, leading to the typical "frothy" RR contents consistence; the absence of a dorsal gas dome would also explain why the dorsal rumen wall of browsers is usually evenly papillated (Hofmann 1973).

One of the major determinants of RR fluid viscosity is saliva viscosity. Larger parotid salivary glands were doc- 
umented in browsing as compared to grazing ruminants (Kay 1987b; Hofmann 1989; Robbins et al. 1995). From this morphological finding, it was deducted that browsers could have higher salivary flow rates than grazers (Hofmann 1989). In contrast, Robbins et al. (1995) did not find a difference in resting salivary flow rate between mule deer, wapiti, and cattle. Regarding the statement of Edrise et al. (1986) that "it appears that the omasum helps to counteract the very great drain on body water imposed by high saliva production...," a smaller omasum in browsers than in grazers (see above) would not make sense if these animals had higher salivary flow rates. Saliva viscosity was not investigated quantitatively in different ruminant species. The only observation stems from Robbins et al. (1987, 1995) who noted that "mule deer saliva... was very viscous with a gelatinous consistency similar to raw egg albumen, whereas cow and sheep saliva was thin and watery." Saliva from mule deer contained 2-3 times as much nitrogen as sheep and cow saliva (Robbins et al. 1987). Investigations of the parotid gland of domestic sheep and cattle led Van Lennep et al. (1977) and Suzuki et al. (1981) to the conclusion that the respective glands' ultrastructure reflected its role in excreting large amounts of fluid with little protein. Likewise, Stolte and Ito (1996) found that the parotis ultrastructure of a series of grazing ruminants (Père David's deer Elaphurus davidianus, European mouflon O. ammon musimon, African buffalo Syncerus caffer, and sable antelope Hippotragus niger) was typical for the secretion of large amounts of fluid with very little protein. The intercellular spaces and secretory canaliculi were well developed and the cells possessed numerous large mitochondria. In browsers (roe deer C. capreolus, nyala Tragelaphus angasii), the same authors found that the secretory canaliculi and intercellular spaces were not as predominant, and the organelles of the parotid acinar cells were more typical of protein-secreting cells. Considering the difference in the recorded parotid gland size, one could speculate that the larger glands of browsers do not produce a larger volume but a more proteinaceous, viscous saliva.

The hypothesis that fast liquid passage from the RR and the production of less viscous saliva are physiological adaptations typical for grazing ruminants, gains circumstantial support from investigations on a digestive problem in domestic ruminants - frothy bloat. The consistency of the RR contents of browsing ruminants was repeatedly described as an unstratified, homogenous, and frothy mass (Hofmann 1973; Nygren and Hofmann 1990; Renecker and Hudson 1990; Clauss et al. 2001); this description suggests that the RR contents of browsers and domestic ruminants with frothy bloat could be similar to a certain degree. Cattle susceptible to bloat were demonstrated to have longer $\mathrm{MRT}_{\text {fluid }} \mathrm{RR}$ and a less distinct selective particle retention (Majak et al. 1986; Okine et al. 1989), lesser saliva production (Mendel and Boda 1961; Gurnsey et al. 1980), and higher RR contents viscosity (Meyer and Bartley 1971, 1972; Clarke and Reid 1974; Sakauchi and Hoshino 1981). The application of substances that prevent bloat lead, at least partially, to faster $\mathrm{MRT}_{\text {fluid }} \mathrm{RR}$ (Branine and Galyean 1990) and a reduced viscosity (Meyer and
Bartley 1972; Stanford et al. 2001). Hence, faster $M_{R T} T_{\text {fluid }}$ $\mathrm{RR}$, increased relative RR outflow and an increased production of a less viscous saliva might be characteristic physiological adaptations of the digestive tract of large grazing ruminants. These characteristics might be more prominent in the Bovinae than in other grazing ruminants.

The consequence of these adaptations would be the distinct RR contents stratification with a "raft" or "mat" floating on top of a fluid layer. Both a high saliva production/fluid throughput and a low saliva viscosity guarantee that the RR fluid is of a consistently low viscosity that allows flotation and sedimentation processes to occur. Thus, the tendency of the longish, fiber-shaped particles into which grasses disintegrate (Clauss et al. 2003), and which display a distinct change in functional density when being digested (Nocek and Kohn 1987; Bailoni et al. 1998) to either cohere in a raft/mat layer or sink to the bottom of the RR according to digestion status, is reinforced. This mechanism ensures a distinct selective particle retention in grazers with its high fiber digestibilities (Iason and Van Wieren 1999; Pérez-Barbería et al. 2004) and very effective particle size reduction (Clauss et al. 2002), but necessitates a larger omasum (Hofmann 1973, 1989) with a larger surface for water reabsorption.

Further research on wild ruminant species is necessary to corroborate or modify these assumptions and to generate sufficient data for a phylogenetically controlled statistical analysis. Any further experimental work should aim at comparing passage characteristics between species consuming their natural forage at both ad libitum and at the same intake level (i.e., for species with the higher ad libitum intake levels, a second run with a restricted feeding period should follow). In particular, MRTs should be determined in a larger variety of species, and the comparative viscosity of saliva and/or RR fluid of different ruminant species should be investigated.

Acknowledgements We thank Matthias Lechner-Doll and John Gross for sharing their respective original data sets.

\section{References}

Amici A, Bartocci S, Terramoccia S, Martillotti F (1997) Passage rate of solids and fluids in the digestive tract of buffaloes, cattle and sheep: selection of non-linear model. Anim Sci 64:63-69

Arthun D, Holechek JL, Wallace JD, Gaylean ML, Cardenas M (1992) Forb and shrub effects on ruminal fermentation in cattle. J Range Manage 45:519-522

Bailoni L, Ramanzin M, Simonetto A, Obalakov N, Schiavon S, Bittan G (1998) The effect of in vitro fermentation on specific gravity and sedimentation measurements of forage particles. J Anim Sci 76:3095-3103

Bartocci S, Amici A, Verna M, Terramoccia S, Martillotti F (1997) Solid and fluid passage rate in buffalo, cattle and sheep fed diets with different forage to concentrate ratios. Livest Prod Sci 52:201-208

Behrend A (2000) Kinetik des Ingestaflusses bei Rehen und Mufflons im saisonalen Verlauf. Dissertation, Berlin 
Behrend A, Lechner-Doll M, Streich WJ, Clauss M (2004) Comparative faecal excretion, gut fill, and solute and particle marker retention in mouflon (Ovis ammon musimon) and roe deer (Capreolus capreolus). Acta Theriol 49:503-515

Branine ME, Galyean ML (1990) Influence of grain and monensin supplementation on ruminal fermentation, intake, digesta kinetics and incidence and severity of frothy bloat in steers grazing winter wheat pasture. J Anim Sci 68:1139-1150

Burns JC, Pond KR, Fisher DS, Luginbuhl JM (1997) Changes in forage quality, ingestive mastication, and digesta kinetics resulting from switchgrass maturity. J Anim Sci 75:13681379

Clarke RTJ, Reid CSW (1974) Foamy bloat of cattle. A review. J Dairy Sci 57:753-785

Clauss M, Lechner-Doll M (2001) Differences in selective particle retention as a key factor in the diversification of ruminants. Oecologia 129:321-327

Clauss M, Deutsch A, Lechner-Doll M, Flach EJ, Tack C (1998) Passage rate of fluid and particle phase in captive giraffe. Adv Ethol 33:98

Clauss M, Lechner-Doll M, Behrend A, Lason K, Lang D, Streich WJ (2001) Particle retention in the forestomach of a browsing ruminant, the roe deer. Acta Theriol 46:103-107

Clauss M, Lechner-Doll M, Streich WJ (2002) Faecal particle size distribution in captive wild ruminants: an approach to the browser/grazer-dichotomy from the other end. Oecologia 131:343-349

Clauss M, Lechner-Doll M, Streich WJ (2003) Ruminant diversification as an adaptation to the physicomechanical characteristics of forage. A reevaluation of an old debate and a new hypothesis. Oikos 102:253-262

Clauss M, Lechner-Doll M, Streich WJ (2004) Differences in the range of faecal dry matter content between feeding types of captive wild ruminants. Acta Theriol 49:259-267

Colucci PE, Macleod GK, Grovum WL, McMillan I (1984) Comparative digestion and digesta kinetics in sheep and cattle. Can J Anim Sci 64:173-174 (Suppl)

De Vaga A, Poppi DP (1997) Extent of digestion and rumen condition as factors affecting passage of liquid and digesta particles in sheep. J Agric Sci (Camb) 128:207-215

Demment MW, Van Soest PJ (1985) A nutritional explanation for body-size patterns of ruminant and nonruminant herbivores. Am Nat 125:641-672

Ditchkoff SS (2000) A decade since 'diversification of ruminants': has our knowledge improved? Oecologia 125:82-84

Dixon RM, Milligan LP (1985) Removal of digesta components from the rumen of steers determined by sieving techniques and fluid, particulate and microbial markers. Br J Nutr 53:347-362

Edrise BM, Smith RH (1979) Absorption and secretion in the omasum of the young steer. Ann Rech Vet 10:354-355

Edrise BM, Smith RH, Hewitt D (1986) Exchanges of water and certain water-soluble minerals during passage of digesta through the stomach compartments of young ruminant bovines. Br J Nutr 55:157-167

Faichney GJ (1980) The use of markers to measure digesta flow from the stomach of sheep fed once daily. J Agric Sci (Camb) 94:313-318

Faichney GJ, Griffiths DA (1978) Behaviour of solute and particle markers in the stomach of sheep given a concentrate diet. $\mathrm{Br} \mathrm{J}$ Nutr 40:71-82

Foose TJ (1982) Trophic strategies of ruminant versus nonruminant ungulates. Ph.D. Thesis, University of Chicago

Freudenberger DO, Burns CJ, Toyokawa K, Barry TN (1994) Digestion and rumen metabolism of red clover and perennial ryegrass/white clover forages by red deer. J Agric Sci (Camb) 122:115-120

Funk MA, Galyean ML, Branine ME, Krysl LJ (1987) Steers grazing blue grama rangeland throughout the growing season. I. Dietary composition, intake, digesta kinetics and ruminal fermentation. J Anim Sci 65:1342-1353

Goetsch AL, Galyean ML (1982) Effect of dietary concentrate level on rumen fluid dilution rate. Can J Anim Sci 62:649-652
Gordon IJ, Illius AW (1994) The functional significance of the browser-grazer dichotomy in African ruminants. Oecologia 98:167-175

Gross JE, Alkon PU, Demment MW (1996) Nutritional ecology of dimorphic herbivores: digestion and passage rates in Nubian ibex. Oecologia 107:170-178

Grovum WL, Williams VJ (1973) Rate of passage of digesta in sheep: III. Differential rates of passage of water and dry matter from the reticulo-rumen, abomasum and caecum and proximal colon. Br J Nutr 30:231-240

Gurnsey MP, Jones WT, Reid CSW (1980) A method for investigating salivation in cattle using pilocarpine as a sialagogue. NZ J Agric Res 23:33-41

Hatt JM (1996) Observations on the digestive strategies of giraffes in captivity. MSc Thesis, The Royal Veterinary College, Institute of Zoology, London

Hatt JM, Lechner-Doll M, Mayes B (1998) The use of dosed and herbage n-alkanes as markers for the determination of digestive strategies of captive giraffes. Zoo Biol 17:295-309

Hauffe R, von Engelhardt W (1975) Funktionen des Blättermagens bei kleinen Hauswiederkäuern. III. Resorption von Wasser. Zbl Vet Med A 22:283-295

Hendricksen R, Poppi D, Minson D (1981) The voluntary intake, digestibility and retention time by cattle and sheep of stem and leaf fractions of a tropical legume. Austr J Agric Res 32:389398

Hjeljord O, Sundstol F, Haagenrud H (1982) The nutritional value of browse to moose. J Wildl Manage 46:333-343

Hofmann RR (1973) The ruminant stomach. East African Monographs in Biology, vol 2. East African Literature Bureau, Nairobi, Kenia

Hofmann RR (1989) Evolutionary steps of ecophysiological adaptation and diversification of ruminants: a comparative view of their digestive system. Oecologia78:443-457

Holand O (1994) Seasonal dynamics of digestion in relation to diet quality and intake in European roe deer. Oecologia 98:274-279

Hummel J (2003) Ernährung und Nahrungsaufnahmeverhalten des Okapis (Okapia johnstoni) in Zoologischen Gärten. Dissertation, Bonn

Iason GR, Van Wieren SE (1999) Adaptations of mammalian herbivores to low quality forage. In: Olff H, Brown VK, Drent $\mathrm{RH}$ (eds) Herbivores, plants and predators. Blackwell Science, Oxford, pp 337-369

Illius AW, Gordon IJ (1992) Modelling the nutritional ecology of ungulate herbivores: evolution of body size and competitive interactions. Oecologia 89:428-434

Jacques K, Harmon DL, Croom WJ, Hagler WM (1989) Estimating salivary flow and ruminal water balance of intake, diet, feeding pattern, and slaframine. J Dairy Sci 72:443-452

Jiang Z, Hudson RJ (1996) Digestive responses of wapiti to seasonal forages. Acta Theriol 41:415-423

Kaske M, Groth A (1997) Changes in factors affecting the rate of digesta passage during pregnancy and lactation in sheep fed on hay. Reprod Nutr Dev 37:573-588

Kattnig RM, Pordomingo AJ, Schneberger AG, Duff GC, Wallace JD (1992) Influence of saline water on intake, digesta kinetics, and serum profiles of steers. J Range Manage 45:514-518

Kay RNB (1987a) Comparative studies of food propulsion in ruminants. In: Ooms LAA, Degtyse AD, Van Miert ASJ (eds) Physiological and pharmacological aspects of the reticulorumen. Martinus Nijhoff, Boston, pp 155-170

Kay RNB (1987b) Weights of salivary glands in ruminant animals. J Zool (Lond) 211:431-436

Kennedy PM (1985) Influences of cold exposure on digestion of organic matter, rates of passage of digesta in the gastrointestinal tract, and feeding and rumination behaviour in sheep given four forage diets in the chopped, or ground and pelleted form. Br J Nutr 53:159-173

Kennedy PM, McSweeney CS, Welch JG (1992) Influence of dietary particle size on intake, digestion, and passage rate of digesta in goats and sheep fed wheaten hay. Small Rumin Res 9:125-138 
Krysl LJ, Galyean ML, Judkins MB, Branine ME, Estell RE (1987) Digestive physiology of steers grazing fertilized and nonfertilized blue grama rangeland. J Range Manage 40:493-501

Lechner-Doll M, Rutagwenda T, Schwartz HJ, Schultka W, von Engelhardt W (1990) Seasonal changes of ingesta mean retention time and forestomach fluid volume in indigenous camels, cattle, sheep and goats grazing a thornbush savannah pasture in Kenya. J Agric Sci (Camb) 115:409-420

Lechner-Doll M, Kaske M, von Engelhardt W (1991) Factors affecting the mean retention time of particles in the forestomach of ruminants and camelids. In: Tsuda T, Saaski Y, Kawashima $\mathrm{R}$ (eds) Physiological aspects of digestion and metabolism in ruminants. Academic, San Diego, pp 455-482

Ledoux DR, Williams JE, Stroud TE (1985) Influence of forage level on passage rate, digestibility and performance of cattle. J Anim Sci 61:1559-1566

Lindberg JE (1985) Retention time of chromium-labelled feed particles and of water in the gut of sheep given hay and concentrate at maintenance. Br J Nutr 53:559-567

Majak W, Hall JW, Rode LM, Kalnin CM (1986) Rumen clearance rates in relation to the occurrence of alfalfa bloat in cattle. 1 . Passage of water-soluble markers. J Dairy Sci 69:1560-1567

Mambrini M, Peyraud JL (1997) Retention time of feed particles and liquids in the stomachs and intestines of dairy cows. Direct measurement and calculations based on faecal excretion. Reprod Nutr Dev 37:427-442

McCollum FT, Galyean ML (1985) Influence of cottonseed meal supplementation on voluntary intake, rumen fermentation and rate of passage of prairie hay in beef steers. J Anim Sci 60:570577

McNab BK (2002) The physiological ecology of vertebrates. A view from energetics. Cornell Univ. Press, Ithaca, NY

Mendel VE, Boda JM (1961) Physiological studies of the rumen with emphasis on the animal factors associated with bloat. J Dairy Sci 44:1881-1898

Merchen NR, Firkins JL, Berger LL (1986) Effect of intake and forage level on ruminal turnover rates, bacterial protein synthesis and duodenal amino acid flows in sheep. J Anim Sci 62:216-225

Meyer RM, Bartley EE (1971) Bloat in cattle. XV. The relation of viscosity and cell-free polysaccharide content of rumen fluid to feedlot bloat. J Anim Sci 33:1018-1021

Meyer RM, Bartley EE (1972) Bloat in cattle. XVI. Development and application of techniques for selecting drugs to prevent feedlot bloat. J Anim Sci 34:234-240

Moore JA, Poore MH, Swingle RS (1990) Influence of roughage source on kinetics of digestion and passage, and on calculated extents of ruminal digestion in beef steers fed $65 \%$ concentrate diets. J Anim Sci 68:3412-3420

Nocek JE, Kohn RA (1987) Initial particle form and size on change in functional specific gravity of alfalfa and timothy hay. J Dairy Sci 70:1850-1863

Nygren K, Hofmann RR (1990) Seasonal variation of food particle size in moose. Alces 26:44-50

Okine EK, Mathison GW, Hardin RT (1989) Relations between passage rates of rumen fluid and particulate matter and foam production in rumen contents of cattle fed on different diets ad lib. Br J Nutr 61:387-395

Owen-Smith N (1996) Distinctive features of the nutritional ecology of browsing versus grazing ruminants. Z Saugetierkd 62(Suppl 2):176-191

Pérez-Barbería FJ, Elston DA, Gordon IJ, Illius AW (2004) The evolution of phylogenetic differences in the efficiency of digestion in ruminants. Proc Biol Sci 271:1081-1090

Poncet C, Al Abd A (1984) Particulate and fluid passage studies in sheep fed a hay-based diet. Can J Anim Sci 64:77-79 (Suppl)

Poppi DP, Minson DJ, Ternouth JH (1980a) Studies of cattle and sheep eating leaf and stem fractions of grasses. I. The voluntary intake, digestibility and retention time in the reticulo-rumen. Austr J Agric Res 32:99-108
Poppi DP, Minson DJ, Ternouth JH (1980b) Studies of cattle and sheep eating leaf and stem fractions of grasses. II. Factors controlling the retention of feed in the reticulo-rumen. Austr J Agric Res 32:109-121

Prigge EC, Baker MJ, Varga GA (1984) Comparative digestion, rumen fermentation and kinetics of forage diets by steers and wethers. J Anim Sci 59:237-245

Renecker LA, Hudson RJ (1990) Digestive kinetics of moose, wapiti and cattle. Anim Prod 50:51-61

Robbins CT, Mole S, Hagerman AE, Hanley TA (1987) Role of tannins in defending plants against ruminants: reduction in dry matter digestion? Ecology 68:1606-1615

Robbins CT, Spalinger DE, Van Hoven W (1995) Adaptation of ruminants to browse and grass diets: are anatomical-based browser-grazer interpretations valid? Oecologia 103:208-213

Sakauchi R, Hoshino S (1981) Effects of monensin on ruminal fluid viscosity, $\mathrm{pH}$, volatile fatty acids and ammonia levels, and microbial activity and population in healthy and bloated feedlot steers. J Anim Physiol Anim Nutr 46:21-33

Shaver RD, Satter LD, Jorgensen NA (1988) Impact of forage fiber content on digestion and digesta passage in lactating dairy cows. J Dairy Sci 71:1556-1565

Sokal RR, Rohlf FJ (1997) Biometry, 3rd edn. Freeman, NY

Spalinger DE, Robbins CT, Hanley TA (1993) Adaptive rumen function in elk and mule deer. Can J Zool 71:601-610

Stanford K, Wang Y, Berg BP, Majak W, McCartney DH, Baron V, McAllister TA (2001) Effects of alcohol ethoxylate and pluronic detergents on the development of pasture bloat in cattle and sheep. J Dairy Sci 84:167-176

Stolte M, Ito S (1996) A comparative ultrastructural study of the parotid gland acinar cells of nine wild ruminant species. Eur J Morphol 34:79-85

Suzuki S, Nishinakagawa H, Otsuka J, Mochizuki K (1981) Fine structure of the bovine parotid gland. Jap J Vet Sci 43:169-179

Tafaj M, Steingass H, Drochner W (2001) Influence of hay particle size at different concentrate and feeding levels on digestive processes and feed intake in ruminants. 2. Passage, digestibility and feed intake. Arch Anim Nutr 54:243-259

Tafaj M, Kolaneci V, Maulbetsch A, Steingass H, Drochner W (2002) Relationship between chewing activity, passage rate and nutrient digestibility in dairy cows. Savrem Pljopr 51:105-109

Tatman WR, Judkins MB, Krysl LJ, Moss GE (1991) Gastrointestinal digesta passage and fermentation patterns associated with restricted intake of a low-quality forage in ewes. Small Rumin Res 4:393-399

Udén P, Colucci PE, Van Soest PJ (1980) Investigation of chromium, cerium and cobalt as markers in digesta. Rate of passage studies. J Sci Food Agric 31:625-632

Udén P, Rounsaville TR, Wiggans GR, Van Soest PJ (1982) The measurement of liquid and solid digesta retention in ruminants, equids and rabbits given timothy (Phleum patrense) hay. Br J Nutr 48:329-339

Van Bruchem J, Schutte AJ, Bangma GA, Leffering CP, Van Adrichem PWM (1984) Dilution rate of a liquid and particulate phase marker in the reticulorumen of sheep. Can J Anim Sci 64:72-73 (Suppl)

Van Lennep EW, Kennerson AR, Compton JS (1977) The ultrastructure of the sheep parotid gland. Cell Tissue Res 179:377392

Varga GA, Prigge EC (1982) Influence of forage species and level of intake on ruminal turnover rates. J Anim Sci 55:1498-1504

Warner ACI (1981) Rate of passage of digesta through the gut of mammals and birds. Nutr Abstr Rev B 51:789-820

Woodall PF, Skinner JD (1993) Dimensions of the intestine, diet and faecal water loss in some African antelope. J Zool (Lond) 229:457-471 